\title{
Global Village Communications
}

\section{Canadian Forests Internet Site}

\section{Growing Interest in the Internet}

During the past two years there has been an explosion of interest in the Internet as a tool for the exchange and dissemination of information. In Canada alone, it is estimated that there are now more than 5 million people connected to the internet, at work or at home, with hundreds of new users coming on board every week. As personal computers have proliferated during the past 15 years, so will internet connections continue to proliferate in the years to come. The low cost of using the internet and the large audiences that can be reached have attracted many organizations to use it as a front line.

\section{The Internet and Forestry}

Public Education and Awareness Building - The use of Canadian forest lands is one of the most contentious issues in public debate today. Canadian forestry has suffered from a low public image both in Canada and internationally, particularly in our important markets in the United States and Europe. The popular misconception is that of a once pristine, natural paradise laid to waste by industrial clearcutting and public mismanagement. Fortunately, this attitude has been changing due to the commendable public education efforts of government, industry, and the professional and industrial associations. The image of a forest industry that is making major steps towards sustainable forest management and of a public administraiton that is seeking a balance in land use, is now getting through. However, the power of the Internet has not been tapped yet to get forestry's messages across. True, there are some good Web presentations, examples include those of the Model Forest Program of Natural Resources Canada TEMBEC Inc., the Canadian Institute of Forestry, and Lakehead University, but much more can be done.
Marketing on the Internet - The internet can also be a powerful marketing tool, permitting any company to reach out to its customers in the global marketplace. An internet site can be a cost-effective, 24-hours a day, 7-days a week, company brochure or prospectus for reaching a huge audience with its message. Electronic mail on the internet allows users to exchange correspondence instantly - far faster and far cheaper than either mail, telephone, fax, or courier services. The forest industry, consultants, service and supply companies can all benefit from the internet in expanding their markets and client base. However, most of the existing sites have not been aggressively marketed to insure that their target audiences know about them.

Internet Made Easy? - One of the persistent problems, especially for new users of the internet, is the difficulty of finding the information you are looking for. One of the major search engines, Alta Vista, has over 30 million sites in its database! Its easy to understand that finding information about forestry in Canada can be a challenging prospect. The internet could be a more effective communications tool for the Canadian forestry industry if there was one forestry site that could act as a gateway to all the others. Until recently, there has not been such a site; information is scattered everywhere and finding it can be a frustrating experience of spending hours of unproductive "surfing" only to find a small part of what is out there. A new internet site has been developed to address this problem.

\section{Canadian Forests Web Site}

In response to the need to have one Internet entry point, the Canadian Forests site has been created. It is the most comprehensive Internet site on forests and forestry in Canada with over 200 entries. It acts as a gateway to all of the important Canadian sites by providing links to:

- Federal Government Departments

- Provincial Government Agencies

- Education and Research Institutions

- Non Governmental Organizations and Associations

- Canadian Forest Industries

- Service and Suppliers

- Canadian Consultants

- Information and Global Links

In addition to developing the site, we will be marketing Canadian Forests to all of the major audiences interested in forests and forestry in Canada. So far, it has been registered with the principal search engines and directories on the internet and has been extensively promoted via email. We are currently developing email databases of target audiences to make aware of this facility and the periodic changes we will be making to it. Audiences include public interest groups, schools, forest industry, media, professional associatoins, and governments in Canada, USA, Europe, and the Pacific Rim countries.

It is truly Canadian in character and national in scope, covering the sector from coast to coast. If you have not visited it yet, the address is <http://www.infoserve. net:80/forest/canfor.html >; it is a "registration-free" service. If you have a site you would like to register, contact us at the email address given below. We would like to get some feedback from you, so take a look at the site and tell us what you think. Hope you like it and I look forward to hearing from you.

John Roper roper@unix.infoserve. net 


\section{Forestry Today on The Web}

\section{http://www.forestry.com/forestry}

"The Information Highway" is rapidly becoming the place to be. There are an estimated 50 million people already "on line" and this number is growing at a rate of 3000 new subscribers per hour!

This technology cannot be ignored. It is the way of the future and the future is now.

At Forestry Today we have constructed our own "home page." To those of you reading this who knows nothing about the information highway or what a home page is, let me briefly explain.

Picture the biggest shopping mall in the world. This is the information highway. Now picture a store in that mall, this is a home page.

As you enter the mall, you are met with so much information you hardly now where to begin. There is no information booth. That's where we come in.

At Forestry Today we are interested in promoting Canadian Forestry and Canadian Forestry Communities.

When you go looking for forestry information you must literally search out, find and view available information one site at a time. This is costly, time consuming and frustrating.

\section{What Makes Our Home Page Different?}

At Forestry Today we have spent months searching the internet and gathering available forestry information. We posted this information on our home page and made it available to users, free of charge. By doing this we have eliminated the frustrations encountered when trying to find what you're looking for. You don't have to search any more, we did it for you. All you have to do is visit our site, scan the index, and with the click of a mouse we will link you to your place of interest. You don't have to type in the complicated addresses, you don't have to search around the globe and what is most important, you don't have to be a rocket scientist to use it. We compare it to "one stop shopping."

\section{What Can our Home Page do for You?}

It is fine for me to explain our Home Page to you, but most people not familiar with the World Wide Web want to know about the bottom line. What will it cost?

\section{EXTENSION FORESTRY SPECIALIST University of Alaska Fairbanks}

The Alaska Cooperative Extension, University of Alaska Fairbanks (UAF) is inviting applications for the Extension Forestry Specialist available immediately and based on the UAF campus in Fairbanks, Alaska.

The position reports to the Extension Land Resources Program Leader, serves forestry interests throughout the state and has the following responsibilities: plan, implement and evaluate statewide Extension forestry programs including, but not limited to, silviculture, forest resource management and forest products utilization; provide technical assistance for and assist land resources Extension agents in identifying and planning forestry-related programs; test and demonstrate applications of research results; communicate responsible management of forest resources and other information through various media forms; seek grants related to the Extension forestry program; work in close cooperation and coordinate program efforts with the School of Agriculture and Land Resources Management/Agricultural and Forestry Experiment Station; and provide leadership in developing and implementing professional improvement programs for professional foresters and technicians. Audiences include private landowners, loggers, owner/harvesters of small forest products' enterprises, professional land managers, land technicians and agency personnel.

This is a permanent, nine month, tripartite, tenure track faculty position. The remaining three months employment may be accommodated through grants acquired by the specialist, or possible joint appointments with other UAF units. Required qualifications are: $\mathrm{PhD}$ with two degrees (Ph.D. \& M.S.; M.S. \& B.S.; Ph.D. \& B.S.) in forest management or closely related field; skills in developing cultural backgrounds. Preferred are: three years experience in applied research; Extension forestry experience; ability to work with agencies, organizations and individuals; and evidence of grant-writing skills.

Applications postmarked later than 2 December, 1996 will not be considered. Please direct inquiries and applications consisting of a letter of application discussing experience relative to each required and preferred qualification; a curriculum vitae; official transcripts of all academic work; and three letters of reference from people who may be contacted and are familiar with the applicant's qualifications to:

Julie Shalvoy, Personnel, Alaska Cooperative Extension, University of Alaska Fairbanks, Room 110 , AHRB, P.O. Box 756180, Fairbanks, AK 99775-6180. TEL (907) 474-7963; FAX (907) 474-7439.

First, our site has two basic uses. One is for research and the other is for business. If you are using our site for research, there is no charge. By providing free access to research we do not restrict anyone from using our site. We also do not restrict access to anyone wanting to do business with companies listed on our site. By providing free access we will attract thousands of visitors from around the world who are interested in Canadian Forestry. If their purpose is research, they will also see an opportunity to do business with companies listed on our site. If it is business they are interested in, they will discover a research tool like no other on the net. This will keep them coming back.

\section{How do you make money off our Home Page?}

Simply put, your company rents space on our site, your own store, so to speak. You can list your services, complete with text, colour pictures or video. The choice is yours. You can list anything from a business address and phone number, to a full length video of a piece of equipment and how it works. You can include a catatlogue, complete with prices, your promotional brochure, a map showing your location or any number of things you want to tell your customers. Customers view your ser- vices and call you direct to place their order. By using our technology you have the opportunity to reach over 50 million potential customers around the world.

\section{Canadian Forestry in the $\mathbf{2 1}$ st Century}

At Forestry Today we are dedicated to promoting Canadian Forestry across Canada and around the world. Canada is a world leader in the field of forestry and proud of it. We control $10 \%$ of the world's forest, $31 \%$ of the world's newsprint market, $16 \%$ of the world's softwood lumber market and generate more jobs and money than every other major Canadian industry combined!

The next logical step for the Canadian Forest Industry is to be the first country in the world to develop an organized presence on the internet and present it to the world. "If you build it, they will come." Join us as we bring the Canadian Forest Industry into the 21 st Century.

Forestry Today

P.O. Box 1, Port Hawkesbury, NS

Canada, BOE 2 VO

Phone: 1 (902) 625-2365

Fax 1 (902) 625-1132

email:waddie@atcon.com

Homepage:

http://www.forestry. com/forestry From Forestry Today 


\section{The Changing Face of Communication}

To stay current with changing times, we need to take frequent time-outs from the same old grind and ask ourselves the question: "What are the top three issues happening right now in my discipline?" Although I'm a forester by training, in my case the discipline is public relations. I just returned from a detailed time-out at the Public Relations Society Counselors Academy meeting in Coronado, California, where we explored the most crucial issues in public relations. As chair of SAF's Education and Communication Working Group (F3), whose mission is to improve members' understanding of communications techniques and their application, I focused on what current communications trends and issues mean for forestry.

We should use "cyberspace" properly. Although we can now move data at electronic speed, we have to remember that information is not communication until a human mind accepts it. As professional foresters, we have to be in cyberspace because information on our issues is already there. Sure, people have acquired faster computers and online services. However, they still have their original brains, full of familiar ideas and resistance to new ones, so settling issues still takes long-term commitment.

Communicating in cyberspace can bet a lot of information to a lot of people fast. It can also get a lot of misinformation to a lot of people fast. In moving an issue through cyberspace the ultimate target is still the human mind. Minds engaged in an issue will resist being pushed too quickly. Minds not engaged in an issue will ignore the information. Yes, we should get on the 'Net, but let's keep the rules of human communciation in mind.

Let's not forget the print media. If print is dead, then who is using all the ink and paper? The presumed death of the print media is premature. People still seek details in print when exploring an issue. Print media and the detailed examination of information that it allows are still important in communicating issues. The people who take action and make a difference want to read about the issues.

Indications are that advertisers are coming back to the print media after a period of moving major expenditures to television. They are learning once again that print is still an important communications vehicle. Publications such as USA Today and others are finding ways to get readers to interact with their messages. Readers' responses, which are used to measure their reactions and demographic characteristics, are bringing advertisers back to focused print media in order to send targeted messages to targeted audiences.

Let's consider changing our approach. if we encounter a "problem public" that doesn't like what we do, we can keep doing it and send out messages explaining why they should like it. The alternative is to change what we do and send out messages about how we've changed. We are beginning to realize that effective public realtaions involves much more than trying to change the behavior of a problem public. Sometimes the public is not going to change until the communicators change. Our profession's survival may depend on changing people's minds; it may also depend on changing the profession's behavior.

The four elements of successful public relations efforts are research, planning, implementation, and evaluation. Some organizations shortchange basic research so they can get on with the work, then they tend to skip detailed evaluation at the end of a project so they can get on to the next thing. Starting with a guess and ending with one is not good policy. Let's not asssume that we know the answer without detailed research and analysis.

Telling oursleves that we can best reach and influence the public by changing our own behavior is uncomfortable. however, it may be the best advice we can give. Lester DeCoster From The Forestry Source, SAF

\section{Web Site - Canadian Forests}

Canadian Forests is the most comprehensive Web site on forests and forestry in Canada. It provides links to the sites of the federal government, the provincial governments, industry, NGOs, associations, educational and research institutions, consultants, suppliers and service, as well as global links to other information sources on Canadian forestry.

The site has been recently updated and we invite you to visit it at:

$<$ http://www.infoserve.net:80/forest/ canfor. html>

John Roper

\section{AlFM Homepage on the Internet}

The date 7 November 1995 was historic for the ASEAN Institute of Forest Management (AIFM) when it installed its own Homepage (Web Page) on the Internet to promote information exchange globally, and in particularly within the ASEAN member countries. Its homepage address is $<$ http://www.jaring.my/ aifm $>$.

Interested parties can now exchange information with the Institute and gain access to its activities and information on forestry resources in the ASEAN region. When all ASEAN member countries are linked through this information technology highway, communication with each other and with the AIFM will be super, enhancing future collaborations within the ASEAN region and beyond.

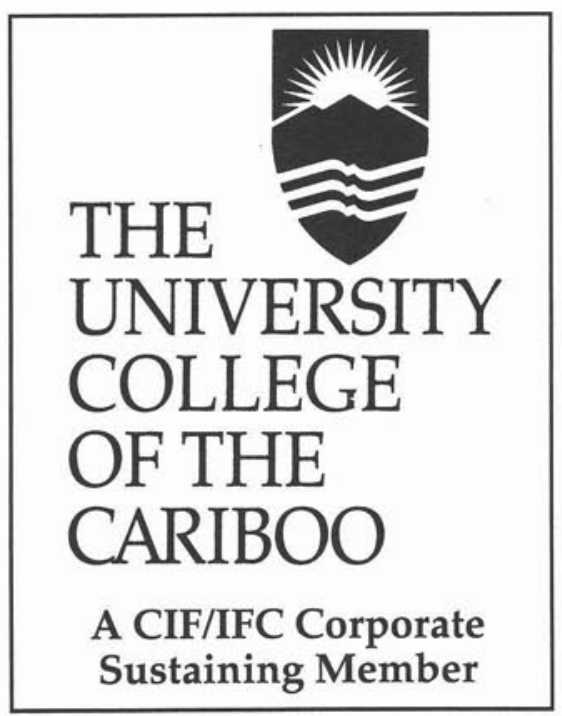

\section{A CIF/IFC Corporate Sustaining Member}

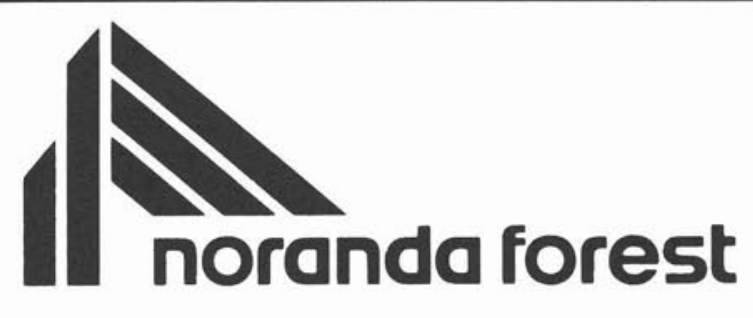

